\title{
KDM2B wt Allele
}

National Cancer Institute

\section{Source}

National Cancer Institute. KDM2B wt Allele. NCI Thesaurus. Code C120058.

Human KDM2B wild-type allele is located in the vicinity of 12q24.31 and is approximately $152 \mathrm{~kb}$ in length. This allele, which encodes lysine-specific demethylase 2B protein, plays a role in histone demethylation. 